\title{
SOCIO-ECONOMIC CONTRIBUTION OF INDIGENOUS CHICKENS TO HOUSEHOLDS IN BORGU LOCAL GOVERNMENT AREA OF NIGER STATE, NIGERIA
}

\author{
M.O. Umunna ${ }^{1}$ *, A.O. Ibrahim ${ }^{1}$, D.O. Oyeleye ${ }^{1}$, M.O. Sodiya ${ }^{3}$, E.O. Adedeji ${ }^{1}$, O.J. Olalekan ${ }^{2}$, \\ O.L. Omotayo ${ }^{1}$ and S.S. Olakayode ${ }^{1}$
}

1- Federal College of Wildlife Management, New Bussa, Niger State. 2- Forest Based Rural Resources

Centre, Forestry Research Institute of Nigeria, Ikija-Ijebu, Ogun State, Nigeria. 3- Federal College of

Forestry, Forestry Research Institute of Nigeria, Ibadan, Nigeria.

*Corresponding author: mathiasumunna@gmail.com +2348139486968

Submitted August 8, 2021; Accepted September 10, 2021; Published 1/10/2021

\section{SUMMARY}

The study assessed the contribution of indigenous chickens to households in Borgu Local Government Area of Niger State, Nigeria. Data were collected with the aid of interview schedule from 80 randomly selected indigenous poultry farmers while descriptive and inferential statistics were used to analyse the data. Findings showed that the average number of local fowls reared was 22.3. Contributions of indigenous poultry farming to households include slaughtering during festivals $(\bar{x}=2.60)$, household consumption as meat and egg $(\bar{x}=2.32)$, money to buy more birds $(\bar{x}=2.23)$ and provision of income for buying food items $(\bar{x}=2.10)$ which were ranked first, second, third and fourth respectively. Constraints to indigenous poultry farming include disease outbreak $(\bar{x}=2.24)$, harsh weather $(\bar{x}=2.20)$, theft and stealing $(\bar{x}=2.20)$ and high cost of feed $(\bar{x}=2.16)$. Farm income $(r=0.339, P=0.011)$, household size $(r=-0.241, p=0.046)$ and constraints $\left(\chi^{2}=58.659, p=0.000\right)$ were significantly related to the specific contribution of indigenous poultry in households. Indigenous rural poultry farming contributes to the households' livelihoods hence there should be increased sensitization on the benefits of raising indigenous poultry as well as giving people training on proper husbandry practices.

Keywords: Indigenous Poultry, Livelihoods, Problems, Specific contribution

\section{INTRODUCTION}

In Africa, household poultry production is practised by more than $80 \%$ of the population, mostly concentrated in rural areas, playing socio-economic roles for rural, urban and peri-urban areas (Fotsa, 2008). Indigenous chickens are known to adapt well to different environment and can survive on limited feed resources that fluctuate in quality according to seasons (Kingori et al., 2007). Though local chickens are slow grower and poor layers of small sized eggs, they are, however, ideal mothers and good sitters (Tadelle, 2003), excellent foragers and hardy (Darwish et al., 1990), and possess natural ability against common diseases (Mtambo, 2000; Dessie et al. (2011). The small body size of native chickens is a desirable character in tropical and subtropical environments. One of the most important positive characters of native chickens is their hardiness, which is ability to tolerate the harsh environmental conditions and poor husbandry practices (climate, handling, watering and feeding) without much loss in production Dessie et al. (2011). Local chickens are part of balanced farming system and have vital roles in the rural households as a source of high quality animal protein and emergency cash income life of the rural community (Padhi, 2016).

Furthermore, chickens have socio-cultural and religious significance (Kondombo et al., 2003; Muchadet et al. (2004); Thekisoe et al. (2004) among rural communities in Africa, and there are few religious taboos associated with consuming chicken meat and eggs. For instance, it has been reported that chickens for many socio-cultural functions or sacrifices are chosen for their sex or plumage colour (Melesse, 2014). Local chickens are used in village medicine and in funeral ceremonies in agrarian communities (Kondombo et al. (2003).

The poultry sub-sector occupies the largest portion of Nigeria's livestock sector and plays a very important role in the livelihoods of people especially the rural dwellers. Free range chicken production represents an important system for supplying the fast growing human population with high quality protein and providing additional income to resource poor small farmers, especially women (Guèye 2009). Human population pressure, the need for high quality versatile foods, especially protein, and increasing levels of income and standards of living have created a tremendous demand for poultry products (FAO, 2000).

Despite, the enormous potentials of the poultry sub-sector in solving the problem of poverty among households, Nigeria still ranks top in poverty level, especially in the rural areas. The poverty headcount rate in Niger State, Nigeria according to NBS (2020) is 66.11 , while it is 40.09 for the entire country. It is based on this background that the study was carried out to assess the contribution of indigenous poultry farming to households socio-economy in Borgu Local Government Area (LGA) of Niger State. The objectives of the study were to identify the specific contribution of indigenous poultry farming to 
households 'livelihood and the constraints faced in rearing the local chickens.

\section{MATERIALS AND METHODS}

The study area is Borgu LGA, Niger State. Borgu LGA is one of the 25 LGAs in Niger state in northern part of Nigeria, with headquarters in New Bussa. Borgu LGA lies between latitude $9^{\circ} \mathrm{N}$ and $11^{\circ} \mathrm{N}$ and longitude $2^{\circ} \mathrm{E}$ and $4^{\circ} \mathrm{E}$. Four wards out of the ten wards in the study area were randomly selected and twenty indigenous poultry farmers were randomly selected from each of the four selected wards to give a sample size of 80 respondents.

Data collection was carried out through the use of interview guide in the randomly selected households in the June 2016. Data collected were analysed using descriptive statistics such as frequency, percentage and means. Inferential statistics, Chi square analysis and Pearson Product Moment Correlation (PPMC) in particular, were used to test for relationship between selected variables in version 17.0 of The Statistical Package for Social Sciences (SPSS) Version 17. Significance was declared at $\mathrm{p}<0.05$.

\section{RESULTS AND DISCUSSION}

Socio-Economic Characteristics:

Table 1 shows that the average age of the respondents was 39.9 years, indicating that the farmers were in their active ages. This implies that the poultry farmers were youthful, hence were able to venture into animal production despite the rate of risk involved. Majority $(54.8 \%)$ of the respondents were female implying that indigenous poultry production is predominantly under the management of women which is similar to results from other African countries (Aklilu, 2007). A very few (13.7\%) of the farmers had no formal education while the remaining farmers had one form of formal education or the other, indicating that majority of the farmers were literate. This could make the adoption of new innovations very easy as well influence the production of the farmers. Majority $(64.4 \%)$ of the respondents were married. The mean family size was 9 , implying a fairly large family size. The implication of this is that the more the household size the more the availability of labour for agricultural ventures like poultry farming. The mean farming experience of 11.5 years shows that the farmers were experienced in poultry farming. The monthly income of $\mathrm{N} 31,194.20$ indicates that the farmers were relatively low income earners. Most of respondents had personal savings $(78.9 \%)$ as their source of fund, $19.7 \%$ had banks as source of fund and $1.46 \%$ obtained their funds from other sources, indicating that majority of the respondents relied of personal savings as source of funds. This has serious implication for the scale of the size of investment which the farmers can make on their farms. The personal savings may be limited in terms of volume, hence the reason for agricultural financing by financial institutions.

Table 1. Socio-economic characteristics of the respondents

\begin{tabular}{|c|c|c|c|c|}
\hline Variable & Frequency & Percentage $(\%)$ & Mean & Standard deviation \\
\hline \multicolumn{5}{|l|}{ Sex } \\
\hline Male & 33 & 45.2 & & \\
\hline Female & 40 & 54.8 & & \\
\hline \multicolumn{5}{|l|}{ Age(years) } \\
\hline$\leq 30$ & 21 & 28.8 & 39.9 & 13.5 \\
\hline $31-40$ & 20 & 27.4 & & \\
\hline $41-50$ & 21 & 28.7 & & \\
\hline$>50$ & 11 & 15.1 & & \\
\hline \multicolumn{5}{|l|}{ Marital status } \\
\hline Single & 15 & 20.5 & & \\
\hline Married & 47 & 64.4 & & \\
\hline Widow & 7 & 9.6 & & \\
\hline Divorced & 4 & 5.5 & & \\
\hline \multicolumn{5}{|l|}{ Educational level } \\
\hline No formal education & 10 & 13.7 & & \\
\hline Primary education & 5 & 6.9 & & \\
\hline Secondary education & 9 & 12.3 & & \\
\hline Tertiary education & 49 & 67.1 & & \\
\hline \multicolumn{5}{|c|}{ Household size (persons) } \\
\hline $1-5$ & 12 & 17.1 & 9 & 4.1 \\
\hline $6-10$ & 43 & 61.5 & & \\
\hline $11-15$ & 10 & 14.3 & & \\
\hline$>15$ & 5 & 7.1 & & \\
\hline \multicolumn{5}{|l|}{ Years of experience } \\
\hline $1-10$ & 43 & 64.2 & 11.5 & 7.2 \\
\hline $11-20$ & 18 & 26.8 & & \\
\hline$>20$ & 6 & 9 & & \\
\hline
\end{tabular}


Table 1. continue

\begin{tabular}{|c|c|c|c|c|}
\hline Monthly income (naira) & & & $31,194.20$ & $30,411.50$ \\
\hline \multicolumn{5}{|l|}{ Source of fund } \\
\hline Personal saving & 56 & 78.9 & & \\
\hline Agricultural bank & 4 & 5.6 & & \\
\hline Micro-finance bank & 4 & 5.6 & & \\
\hline Cooperative bank & 6 & 8.5 & & \\
\hline Others & 1 & 1.4 & & \\
\hline
\end{tabular}

Source: Field survey, 2016

\section{Composition of poultry species reared by} respondents:

Table 2 reveals that majority $(94.5 \%)$ of the respondents with a mean of 22 local fowls per household, $35.6 \%$ with a mean of 30 pigeons, $31.5 \%$ with a mean of 27 guinea fowls and $31.0 \%$ with a mean of 15 ducks engaged in poultry production. This result indicates that local fowls were the most commonly reared indigenous poultry birds in the study area followed by pigeons. The least commonly reared local poultry spp was duck. This finding is similar to that of Moussa et al. (2019) who found that local chickens were the most reared poultry type in Niger followed by guinea fowls and pigeons.

Table 2. Composition of poultry species reared by respondents

\begin{tabular}{lcccc}
\hline Variable & No. of farmers & Percentage & Mean & Standard deviation \\
Local chicken & 69 & 94.5 & 22.3 & 12.6 \\
Guinea fowl & 23 & 31.5 & 27.1 & 15.9 \\
Duck & 31 & 31.0 & 15.0 & 11.2 \\
Pigeon & 26 & 35.6 & 36.0 & 30.0
\end{tabular}

Source: Field survey, 2016

\section{Specific contributions of indigenous poultry production to farmers households:}

Table 3 reveals that slaughtering during festivals $(\bar{x}=2.60)$ had the highest ranking in terms of the specific contribution of indigenous poultry farming to households. This is followed by household consumption as meat and eggs $(\bar{x}=2.32)$ which was ranked the second. This implies that indigenous birds are raised mainly for consumption either to be slaughtered during festivals or for household consumption as meat and eggs. The finding is related to those of Kryger et al. 2010) which reported that income and consumption were the main rationale for keeping village poultry. Using money to buy more birds $(\bar{x}=2.23$ ) was ranked third while provision of income for buying foodstuffs $(\bar{x}=2.10$ ) was ranked fourth. Using the proceeds to take care of children's education $(\bar{x}=2.06)$ was ranked fifth. This result shows that the major contribution of poultry to respondents 'households were slaughtering during festivals, nutritional improvement of the households and income generation for various uses by the households. The finding is similar to that of OseiBonsu and Dery (2009) where they found that livestock farming enabled households to pay for their children school fees and unexpected high cost, such as family health bills. They also found that sales from livestock and their products also enabled poor farmers to put food on the table and improve their nutrition. Given these benefits in support of livelihoods, one can say that livestock has the potential to lift poor households from deprivation to self-sufficiency (Delgado et al., 1999), if the technical and economic constraints are adequately addressed (Thomas and Rangnekar, 2004).

Table 3. Specific contributions of indigenous poultry to households

\begin{tabular}{lccccc}
\hline Specific contribution & High & Moderate & Low & Mean & Ranking \\
\hline Household consumption as meat and egg & $32(44.4)$ & $31(43.1)$ & $9(12.5)$ & 2.32 & $2^{\text {nd }}$ \\
Take care of children education & $25(35.2)$ & $25(35.2)$ & $21(29.6)$ & 2.06 & $5^{\text {th }}$ \\
Provide income for buying food & $26(36.1)$ & $27(37.5)$ & $19(26.4)$ & 2.10 & $4^{\text {th }}$ \\
Provide money to buy household utensils & $16(22.9)$ & $25(35.7)$ & $29(41.4)$ & 1.81 & $8^{\text {th }}$ \\
Provide money to buy clothing & $17(24.6)$ & $23(33.3)$ & $29(42.0)$ & 1.83 & $7^{\text {th }}$ \\
Payment of debts & $15(22.4)$ & $22(32.8)$ & $30(44.8)$ & 1.78 & $9^{\text {th }}$ \\
Slaughtering during festivals & $49(68.1)$ & $17(23.6)$ & $6(8.3)$ & 2.60 & $1^{\text {st }}$ \\
Use money to buy more birds & $30(43.5)$ & $25(36.2)$ & $14(20.3)$ & 2.23 & $3^{\text {rd }}$ \\
For prestige & $13(19.7)$ & $37(56.1)$ & $16(24.2)$ & 1.95 & $6^{\text {th }}$ \\
Provide money for medical & $11(16.7)$ & $27(40.9)$ & $29(42.4)$ & 1.74 & $10^{\text {th }}$ \\
\hline
\end{tabular}

Source: Field survey, 2016 
Problems faced by respondents in rearing

indigenous poultry:

Table 4 shows that disease outbreak $(\bar{x}=2.24)$ was the leading problem facing local poultry farmers. This was followed by harsh weather $(\bar{x}=2.20)$ and theft/stealing ( $\bar{x}=2.20$ ) which had the second ranking. High cost of feed for poultry birds ( $\bar{x}=$ 2.16) was ranked fourth and predators $(\bar{x}=2.09)$ ranked fifth. Outbreak of disease can lead to death and ultimate loss of income to the farmers. The major problems as identified include disease, harsh weather, theft and stealing, and high cost of feeding. Most of the identified problems are as a result of poor housing of the birds. The birds are mainly on semi- intensive management system thus exposing them to the vagaries of weather, predators and theft. It has been reported that poultry birds not housed are exposed to rain, cold, predators, theft which pose management difficulties in inspecting for signs of illness or injury and vaccination against diseases (Ahlers et al., 2009). The result confirms the finding of Alonge et al. (2010) that the greatest constraints of local poultry production by women were disease outbreak and stealing. Moussa et al. (2019) identified incidence of disease, predators, lack of housing, inadequate training and feeding as the major constraints to local poultry production in Niger.

Table 4. Problems faced by respondents in rearing local poultry

\begin{tabular}{lccccc} 
Constraints & Very serious & Mild & Not serious & Mean & Ranking \\
\hline Disease outbreak & $27(40.3)$ & $29(43.3)$ & $11(16.4)$ & 2.24 & $1^{\text {st }}$ \\
Predators & $28(40.0)$ & $20(28.6)$ & $22(31.4)$ & 2.09 & $5^{\text {th }}$ \\
Inadequate skill and knowledge & $18(26.9)$ & $29(43.3)$ & $19(28.4)$ & 2.01 & $7^{\text {th }}$ \\
High cost of feed & $26(37.1)$ & $26(37.1)$ & $17(24.3)$ & 2.16 & $4^{\text {th }}$ \\
No market for chicken in my area & $14(19.7)$ & $25(35.2)$ & $32(45.1)$ & 1.75 & $8^{\text {th }}$ \\
Complaints from neighbours & $14(20.0)$ & $22(31.4)$ & $34(48.6)$ & 1.71 & $9^{\text {th }}$ \\
Harsh weather & $28(39.4)$ & $29(40.8)$ & $14(19.7)$ & 2.20 & $2^{\text {nd }}$ \\
No veterinary assistance & $23(32.4)$ & $27(38.0)$ & $21(29.6)$ & 2.03 & $6^{\text {th }}$ \\
Theft and stealing & $30(42.3)$ & $25(35.2)$ & $16(22.5)$ & 2.20 & $2^{\text {nd }}$ \\
\hline Source Fin
\end{tabular}

Source: Field survey, 2016

Chi-square analysis of respondents 'socio-economic characteristics and specific contributions of indigenous poultry to households livelihoods:

Table 5 shows no significant relationships between sex $(\chi 2=1.27, \mathrm{p}=0.53)$, marital status $(\chi 2=10.50, p=0.10)$ and educational level of the respondents $(\chi 2=10.54, \quad \mathrm{p}=0.395)$, and the contribution of indigenous poultry farming to households 'livelihoods. The result implies that the socio-economic characteristics of the households did not affect the contribution of indigenous poultry farming to their livelihoods.

Table 5. Chi-square analysis of respondents socio-economic characteristics and specific contribution of indigenous poultry to households 'livelihoods

\begin{tabular}{lcccc}
\hline Variable & $\boldsymbol{\chi 2}$ & df & P & Decision \\
\hline Sex & 1.27 & 2 & 0.53 & NS \\
Marital status & 10.50 & 6 & 0.10 & NS \\
Educational level & 10.54 & 10 & 0.39 & NS \\
Major occupation & 9.16 & 8 & 0.33 & NS
\end{tabular}

Source: Field survey, $2016 ; \chi^{2}=$ Chi-square df $=$ degree of freedom $\quad$ NS $=$ not significant

PPMC analysis of respondent socio economic characteristics and specific contribution of indigenous poultry to households livelihoods:

The analysis of Pearson Product Moment Correlation (Table 6) shows that household monthly income $(\mathrm{r}=-0.34, \mathrm{p}=0.01)$ and household size $(\mathrm{r}=$ $0.24, \mathrm{P}=0.05)$ had significant relationships with the specific contribution of indigenous poultry to households 'livelihoods. This implies that both household monthly income and household size are likely to affect the specific contribution of indigenous poultry to households 'livelihoods. The inverse relationship between the household monthly income and the contribution of indigenous poultry to households suggests that keeping local poultry contributed more to low income households than high income households. Similarly, keeping local poultry contributed specifically more to households with larger sizes. 
Table 6. PPMC analysis of respondent socio-economic characteristics and specific contributions of indigenous poultry to households 'livelihoods

\begin{tabular}{lccc}
\hline Variable & r - value & P & Decision \\
Age & 0.10 & 0.40 & $\mathrm{NS}$ \\
Household size & 0.24 & 0.05 & $\mathrm{~S}$ \\
Farming experience & 0.17 & 0.18 & $\mathrm{NS}$ \\
Household monthly income & -0.34 & 0.01 & $\mathrm{~S}$ \\
\hline
\end{tabular}

Source: Field survey, 2016 ; Ns = not significant ; S = significant

Chi-square analysis of constraints faced by respondents in indigenous poultry farming and specific contribution of indigenous poultry to households 'ivelihoods:

Table 7 shows that a significant relationship between constraints faced in indigenous poultry farming $\left(\chi^{2}=58.66, p=0.00\right)$ and specific contribution of indigenous poultry to households' livelihoods. This implies that the constraints faced in indigenous poultry farming can affect the specific contribution of indigenous poultry to households ' livelihoods. Thus, a lot should be done to eliminate the constraints.

Table 7. Chi-square analysis of constraints faced by respondents in indigenous poultry farming and specific contribution of indigenous poultry to households 'livelihoods

\begin{tabular}{lcccc}
\hline Variable & $\chi^{2}$ & df & P & Decision \\
\hline Constraints & 58.66 & 2 & 0.00 & S
\end{tabular}

Source: Field survey, 2016

$\chi^{2}=$ Chi-square $\mathrm{df}=$ degree of freedom $\mathrm{S}=$ significant

Indigenous poultry farming impacts households ' slaughtering of birds during festivals, consumption as meat and egg, using money derived from sales of birds to buy more birds and provision of income for buying foodstuffs. Major constraints to indigenous poultry farming are disease outbreak, harsh weather, theft and stealing. The contribution of indigenous poultry farming to households is influenced by household monthly income, household size and the constraints. It is concluded that rural poultry farming contributes to the households 'livelihoods in the study area. However, for improved contributions, government and other Non-Government Organisations should sensitize the rural dwellers about the contributions and benefits of raising indigenous poultry as well as giving them training on proper husbandry practices, while veterinary services should be provided and made accessible and affordable to the farmers.

\section{REFERENCES}

Ahlers, C., R.G. Alders, B. Bagnol, A.B. Cambaza, M. Harun, R. Mgomezulu, H. Msami, B. Pym, P. Wegener, E. Wethli and M. Young, 2009. Improving village chicken production: A manual for field workers and trainers. ACIAR Monograph No. 139. Australian Centre for International Agricultural Research: Canberra. URLhttp://aciar.go v.au/files/no de/11129 194 pp.

Aklilu, A.H., 2007. Village Poultry in Ethiopia. Socio-technical analysis and learning with farmers. Unpublished Ph.D. Thesis. Wageningen University, Wageningen, The Netherlands.
Alonge, G.O., V.E. Okpeze, E.O. Owolabi, T.A. Adebisi and O.A. Olatunde, 2010. Indigenous management techniques by women local chicken rearers in Ogun State. Proceedings of the 15th Annual Conference of Agricultural Society of Nigeria14-10 .th.92-84 Pp. .2010 May, ,

Darwish, A., N.A. Hataba, and S.M. Shalash, 1990. Effects of seasonal variation and dietary protein level on some performance of Fayoumi layers, in Proceedings of the 3rd International Symposium on Feed and Quality Control pp. Egypt. Cairo,, $.459-443$

Delgado, C., Rosegrant, M., Steninfeld, H., Ehui, S. and Corbois, D.C., 1999. Livestock to 2020: The next food revolution. IFPRI, FAO and ILRI.

Dessie, T., Taye, T. Dana, N. Ayalew, W. and Hanotte, O., 2011. Current state of knowledge on phenotypic characteristics of indigenous chickens in the tropics, World's Poultry Science Journal $.516-507:(3) 67$

FAO, 2000. FAOSTAT. Statistical database of Food and Agriculture Organization of the United Nations, Rome, Italy.

Fotsa, J.C., 2008. Caracterisation des populations de poules locales (Gallus gallus) au Cameroun301.

Guèye, E.F., 2009. The role of networks in information dissemination to family poultry farmers. Small-scale family poultry production. World P. Sci. J. 65:124-115

Kingori, A.M., Tuitoek, J.K., Muiruri, H.K., Wachira A.M and Birech, E.K., 2007. Protein intake of growing indigenous chickens on free-range and their response to supplementation. Int. J. Poult. Sci. 6(9):617-621. 
Kondombo, S. R., A. J. Nianogo, R. P. Kwakkel, H. M. Y. Udo, and M. Slingerl. 2003. Comparative analysis of village chicken production in two farming systems in Burkina Faso. Trop. Ani. Health and Prod. 35:563-574.

Kryger, K.N, Thomsen, K.A, Whyte M.A, and Dissing, M., 2010. Smallholder Poultry Production Livelihoods, Food Security and Sociocultural Significance, Smallholder Poultry Production. FAO. Rome Italy. P. 76.

Melesse, A., 2014. Significance of scavenging chicken production in the rural community of Africa for enhanced food security. World's Poult. Sci. J. 70:593-606

Moussa, H.O., 2019. Indigenous chicken production in Niger. Veterinary and Animal Science..1:7

Mtambo, M. M.A., 2000. Improving the health and productivity of the rural chickens in Africa: report of Phase 1 of an Enreca Sponsored Project, Tech. Rep.

Muchadeyi, F. C., S. Sibanda, N. T. Kusina, J. Kusina, and S. Makuza., 2004. The village chicken production system in Rushinga district of Zimbabwe. (6)16 Dev. Rural for Res. Livst: Available at: http://www.lrrd.org/lrrd16/6/much16040.htm. Accessed: March 15, 2019.

National Bureau of Statistics NBS, 2020. Poverty and inequality in Nigeria- 2019.
Osei-Bonsu, A and Dery, S.K., 2009. The contribution of livestock in livelihoods of coconut-based households in Ghana. Journal of Sustainable Development in Africa. .43 .(4)11

Padhi, M.K., 2016. Importance of indigenous breeds of chicken for rural economy and their improvements for higher production performance. Scientifica. $2016 \quad$ (6):1-9. http://dx.doi.org/10.1155/2016/2604685.

Tadelle, D.S., 2003. Phenotypic and genetic characterization of local chicken ecotypes in Ethiopia [Ph.D. thesis], Humboldt University, Berlin, Germany.

Thekisoe, M.M.O., P.A. Mbati, and S.P.R. Bisschop, 2004. Different approaches to the vaccination of free ranging village chickens against Newcastle disease in Qwa-Qwa, South Africa. .Micro Vet. .30-101:23

Thomas, D. and D.V. Rangnekar, 2004. Responding to the increasing global demand for livestock products. Implications for the livelihoods of the livestock producer in developing countries. Responding to the livestock revolution. The role of globalization and implications for poverty alleviation. British Society of Animal Science. Occasional Publication 33.36-Pp.1 .

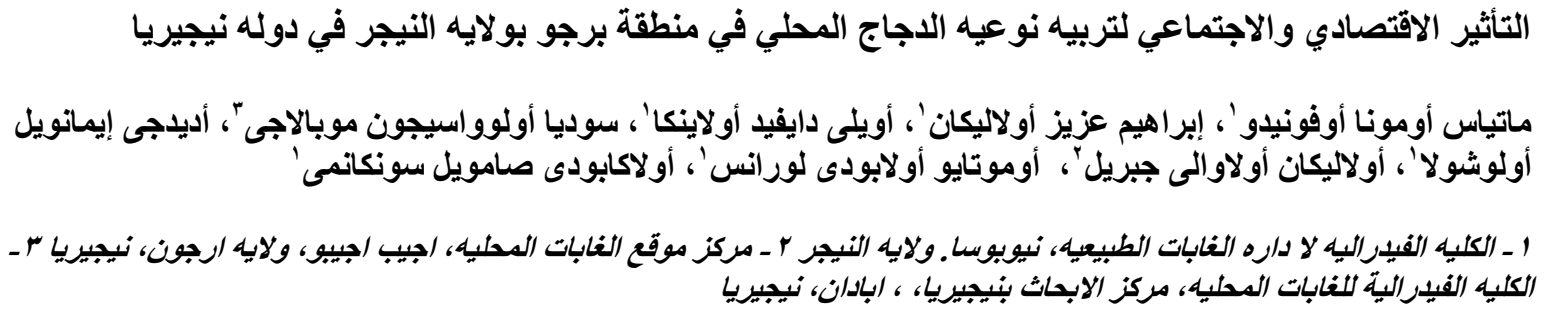

